УДК 159.923.2:387

DOI https://doi.org/10.26661/2310-4368/2021-1-4

\title{
ПСИХОЛОГІЧНІ УМОВИ ПОЗИТИВНОГО ВПЛИВУ ІНТЕРНАЛЬНОСТІ НА САМОРОЗВИТОК МАЙБУТНІХ ПСИХОЛОГІВ: ТЕОРЕТИЧНИЙ АНАЛІЗ
}

\author{
Кетлер-Митницька Т. С. \\ кандидат психологічних наук, \\ стариий викладач кафедри спеціальної педагогіки та спеціальної психології \\ КЗВО «Хортицька національна навчально-реабілітаційна академія» \\ Запорізької обласної ради \\ вул. Наукового Містечка, 59, Запоріжжя, Украӥна \\ orcid.org/0000-0002-1665-4282 \\ catmeatt@gmail.com
}

\begin{abstract}
Ключові слова: особистіснопрофесійний саморозвиток, інтернальність, психологічні умови, оптимістичний атрибутивний стиль, відповідальність, орієнтація на дію.
\end{abstract}

У статті розкрито внутрішні обставини, за яких інтернальність гальмує або стимулює саморозвиток студентів-психологів. Важливість забезпечення особистісно-професійного саморозвитку майбутніх психологів пояснено вимогами до особистісних якостей цих фахівців. Як один із внутрішніх чинників стимулювання саморозвитку розглянуто інтернальність. Розкрито психологічний зміст інтернальності як одного 3 двох полюсів локусу контролю. Обгрунтовано позитивний, але дещо неоднозначний характер впливу інтернальності на готовність майбутніх психологів до особистіснопрофесійного саморозвитку. У результаті теоретичного аналізу виокремлено умови, які провокують негативний вплив інтернальності на саморозвиток, а саме: песимістичний атрибутивний стиль (пояснення невдач стабільними глобальними внутрішніми чинниками); прийняття відповідальності тільки за причини проблем; орієнтація на стан. Проаналізовано характеристики «доброго» та «поганого» інтернального контролю відповідно до наукових поглядів різних дослідників. Сформульовано припущення щодо існування певних внутрішніх умов, за яких інтернальність буде мати більш виражений i однозначний вплив на саморозвиток студентів-психологів. На основі аналізу наукових джерел запропоновано такі умови позитивного впливу інтернальності на саморозвиток: оптимістичний атрибутивний стиль (пояснення невдач варіативними та специфічними, а успіхів - стабільними та глобальними внутрішніми чинниками); прийняття відповідальності за подолання проблем без концентрації на їхніх причинах; орієнтація на дію. Проаналізовано та конкретизовано значення цих умов для особистіснопрофесійного саморозвитку саме студентів-психологів 3 урахуванням змісту та специфіки їхньої майбутньої професійної діяльності. Наведені положення підкріплено експериментальними даними сучасних дослідників. Зроблено висновок про перспективність емпіричної перевірки припущення щодо впливу зазначених умов на характер взаємозв'язку інтернальності та особистісно-професійного саморозвитку студентів-психологів. 


\title{
PSYCHOLOGICAL CONDITIONS OF POSITIVE INFLUENCE OF INTERNALITY ON FUTURE PSYCHOLOGISTS' SELF-DEVELOPMENT: THEORETICAL ANALYSIS
}

\author{
Ketler-Mytnytska T. S. \\ Candidate of Psychological Sciences, \\ Senior Lecturer at the Special Pedagogy and Special Psychology Department \\ Municipal Institution of Higher Education "Khortytsia National Educational \\ and Rehabilitational Academy" of Zaporizhzhia Regional Council \\ Naukove Mistechko str., 59, Zaporizhzhia, Ukraine \\ orcid.org/0000-0002-1665-4282 \\ catmeatt@gmail.com
}

Key words: personal and professional self-development, internality, psychological conditions, optimistic attributive style, responsibility, action orientation.

\begin{abstract}
The article reveals the internal circumstances in which internality inhibits or stimulates the self-development of student psychologists. The importance of ensuring personal and professional self-development of future psychologists is explained by the requirements for personal qualities of these specialists. Internality is considered as one of the internal factors stimulating self-development. The psychological meaning of internality as one of the two poles of the locus of control is revealed. The positive, but somewhat ambiguous nature of the influence of internality on the future psychologists' readiness for personal and professional selfdevelopment is substantiated. As a result of theoretical analysis, the conditions that provoke the negative impact of internality on self-development are identified, namely: pessimistic attributive style (explanation of failures by stable global internal factors); taking responsibility only for the causes of problems; state orientation. The characteristics of "good" and "bad" internal control are analyzed in accordance with the scientific views of various researchers. Assumption is made about the existence of certain internal conditions under which internality will have a more pronounced and unambiguous impact on the self-development of students psychologists. Based on the analysis of scientific sources, the following conditions of the positive influence of internality on self-development are proposed: optimistic attributive style (explanation of failures by variable and specific, and successes - by stable and global internal factors); taking responsibility for overcoming problems without focusing on their causes; action orientation. The significance of these conditions for personal and professional self-development of students-psychologists is analyzed and specified, taking into account the content and specifics of their future professional activity. These provisions are supported by experimental data of modern researchers. The conclusion is made about the prospects of empirical verification of the assumption about the influence of these conditions on the nature of the relationship between internality and personal and professional self-development of students-psychologists.
\end{abstract}

Постановка проблеми. Зростання кількості та інтенсивності дії психотравмуючих чинників, емоційне та інформаційне перевантаження, нестабільність соціально-економічних умов суттєво ускладнюють процес особистісного та професійного становлення сучасної молоді. У цьому контексті дедалі більшої актуальності набуває проблема активізації саморозвитку здобувачів вищої освіти. Заклади вищої освіти покликані підготувати студентів до здійснення емоційної та поведінкової саморегуляції, розвитку у себе про- фесійно важливих якостей, виявлення та корекції недоліків. Це завдання набуває особливої значущості при підготовці майбутніх психологів у зв'язку із високими вимогами до особистісних та комунікативних якостей таких фахівців. На думку Н. Шевченко, цінність саморозвитку, прагнення до самовдосконалення $€$ важливими показниками сформованості професійної спрямованості студентів-психологів [1, с. 99-100]. Як вважає О. Черепєхіна [2, с. 574], засвоєння форм та методів саморозвитку, підвищення свідомого 
прагнення студентів до оволодіння вершинами майстерності належить до базових пріоритетів у підготовці майбутніх психологів.

Оскільки готовність до саморозвитку є комплексним утворенням, сучасними науковцями обгрунтовано доцільність ії підвищення шляхом стимулювання внутрішніх чинників (факторів, корелятів) цієї властивості. Зокрема, до таких чинників належить інтернальність. Це поняття запроваджено Дж. Роттером для позначення внутрішнього локусу контролю особистості за підкріпленням. $€$ одним $з$ полюсів конструкту, в якому інтернальність передбачає очікування людиною бажаних наслідків власних дій на основі приписування причин успіхів та невдач самій собі, а екстернальність, - навпаки, очікування значущих підкріплень як результату позитивного чи негативного впливу сторонніх чинників [3].

Під час розгляду впливу інтернальності на саморозвиток майбутніх психологів у межах суб' Єктного, особистісно-діяльнісного та гуманістичного підходів [4-6] дослідники відзначали переважно його позитивний ефект. I. Варе експериментально встановила, що інтернальність студентів-психологів є одним із чинників сформованості їх смисложиттєвих орієнтацій, які забезпечують високу мотиваційну готовність до професійної самоактуалізації, детермінують напрямки та межі самореалізації [4, с. 73-78]. Як виявила Ф. Рекешаева, інтернальність входить до складу особистісних умов психологічної готовності психолога до професійної діяльності [5]. В. Шахов дослідив інтернальність у контексті подолання складних життєвих ситуацій як чинник вибору таких його стратегій, які спрямовані на самовдосконалення [6, с. 13]. Позитивний вплив інтернальності на саморозвиток можна пояснити тим, що внутрішня локалізація контролю сприяє більшому прийняттю відповідальності за ефективність професійної діяльності, через що підвищує мотивацію роботи над собою. Це підтверджують й результати нашого дослідження.

Водночас характер такого впливу має бути уточнено. За результатами нашого дослідження, не всі прояви інтернальності сприяють готовності майбутніх психологів до особистісно-професійного саморозвитку. Шляхом факторного аналізу показники компонентів інтернальності та готовності до саморозвитку було згруповано нами у 5 факторів, позитивну динаміку яких після експериментального впливу встановлено за допомогою t-критерія Стьюдента. Проте вагоме факторне навантаження 3-проміж усіх проявів цієї властивості отримала тільки інтернальність у сфері досягнень, тоді як загальні показники інтернальності та саморозвитку не мали достатньої ваги та не показали статистично значущих кореляцій [7, с. 209-211].

Крім того, дослідження А. Реана [8], Р. Шаміонова [9] та деяких інших вчених ставлять під сумнів однозначність впливу високої інтернальності на психологічне благополуччя в цілому та саморозвиток зокрема. Ймовірність виникнення невротичних реакцій на кшталт «комплексу провини» внаслідок внутрішньої локалізації контролю науковці пояснюють впливом різних несприятливих внутрішніх обставин.

Зважаючи на це, можна висунути припущення щодо існування певних психологічних умов, які підсилюють позитивний та блокують негативний вплив інтернальності на саморозвиток. Попри високу практичну значущість підвищення готовності до самовдосконалення шляхом стимулювання його внутрішніх чинників, виявлені нами дані щодо умов позитивного впливу інтернальності на саморозвиток майбутніх психологів $\epsilon$ розрізненими та несистематизованими. Отже, доцільним $\epsilon$ аналіз та розкриття таких умов.

Під час використання поняття «психологічна умова» ми спираємося на наукові погляди I. Грузинської, яка визначила цей термін як комплекс взаємообумовлених внутрішніх та зовнішніх явищ, що мають психологічний зміст та відіграють роль обставин, які роблять можливим утворення, формування чи розвиток певних психічних процесів, якостей чи властивостей людської особистості $[10$, с. 100$]$.

Мета статті - виокремити та розкрити психологічні умови позитивного впливу інтернальності на саморозвиток майбутніх психологів.

Виклад основного матеріалу дослідження. Незважаючи на те, що в більшості випадків інтернальність має виражене позитивне значення для становлення особистості, науковці виявили обставини, за яких високий рівень внутрішньої локалізації контролю загрожує психологічному благополуччю. Зазвичай, такі випадки стосуються пояснення невдач, а саме - усвідомлення припущених помилок та визнання своєї провини. 3 одного боку, саме виявлення власної недосконалості (особливо у сфері професійно значущих якостей та вмінь) $є$ першочерговим поштовхом до саморозвитку, логічною передумовою подальшої цілеспрямованої самозміни. Водночас потенціал невдоволення собою може перетворитися у деструктивний поштовх, завдяки якому творчу енергію самотворення буде витрачено на різноманітні прояви аутоагресії.

Теоретичний аналіз дозволив виявити умови негативного впливу інтернальності на саморозвиток, які було узагальнено нами таким чином.

По-перше, песимістичний атрибутивний стиль, який передбачає пояснення невдач вну- 
трішніми стабільними та глобальними чинниками. Впевненість людини в тому, що невдачі спровоковано властивими їй недоліками, зумовлює сприймання неуспіху як постійного (закономірного) та поширеного на всі сфери життя, що цілком відповідає песимістичному когнітивному стилю за М. Селігманом [11, с. 112]. Як встановили Е. Фарес і В. Джеймс, песимістично налаштовані люди навіть після досягнення успіху продовжують очікувати у майбутньому невдач, оскільки спираються на генералізовані очікування негативних подій, причиною яких вважають себе [12, с. 579-581]. Поняття «поганого» внутрішнього контрою запропонував А. Реан, який робив висновок про ступінь корисності інтернальності на основі того, якими внутрішніми причинами людина пояснює свою невдачу: стабільними (здібності, інтелект) або варіативними (наполегливість). «Погана» інтернальність, яка будується на приписуванні собі стабільних причин поганих подій (наприклад, пояснення їх своєю недостатньою розумністю або обдарованістю), призводить до зниження самооцінки та мотивації досягнення успіху, формування комплексу провини, загострення психоемоційної дезадаптації, невротичним проявам [8, с. 68-69]. У такому стані людина не відчуває себе готовою до саморозвитку через брак віри у його результативність, впевненість у безперспективності зусиль щодо самовдосконалення.

По-друге, прийняття відповідальності за причини проблем замість відповідальності за їх подолання. А. Реан розрізняв патерни «хороший інтернальний контроль» та «поганий інтернальний контроль» також за локалізацією прийняття відповідальності. Він виділяв відповідальність за причини невдач та відповідальність за подолання невдач [8, с. 68-69]. «Поганий» інтернальний контроль зумовлює концентрацію не на шляхах подолання проблемної ситуації, а на своїх неправильних діях, словах, емоційних реакціях, які цю ситуацію викликали. Близьку думку висловив Р. Шаміонов, який пов'язував надмірність інтернальності в галузі невдач з гострою невдоволеністю собою [9, с. 48]. Не зважаючи не загальну рефлексивність такої самокритичної позиції, вона не сприяє готовності до саморозвитку через надмірну «зацикленість» особистості на своїх помилках без активних спроб пом'якшити або усунути їх наслідки.

По-третє, орієнтація на стан. Згідно з «моделлю Рубікону», розробленою Х. Хекхаузеном та Ю. Кулем, процес контролю за дією складається 3 чотирьох фаз: мотивація; прийняття рішення; реалізація рішення або власне дія; оцінка результатів дії (аналіз причин своїх успіхів та невдач). Символ перетину Рубікону було використано авторами для відображення переходу від мотивації до активних, рішучих дій [13, с. 320-321]. Ю. Куль запропонував дві диспозиції, пов’язаних 3 цим переходом, які назвав «орієнтацією на стан» та «орієнтацією на дію». Перша 3 них викликає фіксацію на емоційному стані, безперервній рефлексії щодо можливих негативних наслідків запланованих дій. Якщо зріла особистість усвідомлює об'єктивні причини неуспіху, які неможливо контролювати (наприклад, недостатній зріст або рівень матеріальних ресурсів), то зазвичай відмовляється від цього наміру без самозвинувачень та почуття провини. Якщо ж особистість не здатна відмовитися від власного задуму, хоч не бачить наявних можливостей для його втілення, це зумовлює перетворення наміру на неповноцінний («дефектний»). Такий намір ніколи не буде реалізованим, але стане постійним джерелом невдоволення людини собою та своїми досягненнями. Для прикладу неповноцінних намірів Ю. Куль навів опис стану депресивних досліджуваних, які були настільки сконцентровані на думках про перспективу неуспіху, що не розпочинали цілеспрямовану діяльність для досягнення важливої для них мети [14]. Таким чином, інтернальність у поєднанні 3 пасивністю, нерішучістю, побоюванням можливої невдачі гальмує процес саморозвитку, оскільки зумовлює виникнення неповноцінних намірів (на кшталт «почати нове життя 3 понеділка»), які ніколи не втілюються в життя.

На основі вищенаведеного ми сформулювали три основних умови позитивного впливу інтернальності на саморозвиток майбутніх психологів.

1. Оптимістичний атрибутивний стиль, який передбачає пояснення невдач внутрішніми, але тимчасовими й специфічними (що виникають у виняткових ситуаціях) причинами. Навпаки, успіхи сприймаються як стабільні, глобальні і залежні від зусиль індивіда. Важливим проявом оптимістичного атрибутивного стилю $є$ впевненість у загальній спроможності розвивати та виправляти свої розумові та особистісні властивості. На думку Т. Гордєєвої, активній позиції щодо саморозвитку сприяє оцінка людиною своїх якостей, здібностей та інтелекту як таких, що можуть вдосконалюватися $[15$, с. $25-129]$. Як встановили В. Хендерсон та К. Двек, найбільших навчальних успіхів досягають ті учні, які вірять у можливість підвищення власного інтелектуального потенціалу, хоча спочатку вважають його недостатнім [14, с. 308-329]. Отже, інтернальна атрибуція поганих оцінок сприяє саморозвитку школярів за рахунок оптимістичного ставлення до своєї научуваності. Інтернали відрізняються від екстерналів значною мірою саме ставленням до причин невдач. Визнання власного «авторства» помилки 
або провалу є більш інтернальним вчинком, ніж приписування собі причин успішного виконання справи. Воно може значно активізувати мотивацію самовдосконалення за умов оптимістичної оцінки власних перспектив, переконаності в тому, що збільшення старанності, наполегливості, саморегуляції сприятиме досягненню успіху.

Інтернали впевнені у своїй здатності бути успішними у майбутньому на основі спогадів про те, що у багатьох ситуаціях їм вдавалося досягати поставлених цілей завдяки власним зусиллям та здібностям. Позитивне значення зазначеної умови засвідчує й дослідження Л. Малімон та Т. Дучимінської, які виявили вплив оптимістичного атрибутивного стилю та інтернальності на рівні зацікавленості студентів навчальними знаннями та орієнтацію на опанування професією. Саме така мотивація $\epsilon$ важливою передумовою особистісно-професійного саморозвитку [16, с. 136].

2. Приймання відповідальності за подолання проблем без концентрації на їх причинах. За «хорошого інтернального контролю» (за А. Реаном) особистість приділяє більше уваги не причинам проблем, а шляхам їх самостійного подолання, підбирає засоби зміни ситуації на краще. На думку автора, саме інтернальна атрибуція відповідальності за подолання труднощів дозволяє людині зберегти позитивну самооцінку та почуття контролю за подіями власного життя [8, с. 68-69]. Ми цілком погоджуємося $з$ цією думкою, але вважаємо дещо дискусійною іншу властивість «хорошого інтернального контролю», запропоновану А. Реаном, а саме - екстернальність атрибуції причин проблем, що виникли. Адже заперечення людиною власної причетності до складної ситуаціiі, яку вона насправді спровокувала, є викривленням об'єктивних причинно-наслідкових зв'язків, яке, хоч і виконує захисну функцію, проте заважає адекватному поводженню. На нашу думку, ігнорування власних помилок або приписування їх іншим людям може значно знижувати здатність особисті ефективно діяти навіть за умов іiі готовності взяти на себе відповідальність за подолання цієї проблеми.

Нам імпонує позиція Д. Карася, який базовим принципом інтернальної взаємодії зі світом вважає спрямованість людини на практичну зміну різноманітних явищ, подій на основі усвідомлення їх причинно-наслідкових зв'язків зі своєю поведінкою. На думку науковця, інтернальність передбачає спроможність особистості зробити власний вибір та свідомо взяти на себе відповідальність за його наслідки, особливо в умовах невизначеності. Вміння інтерналів самостійно розв'язувати життєві проблеми, використовувати ефективні стратегії поведінки дозволяє говорити про властиву їм «особистісну компетенцію» [17, с. 33-37].
3. Орієнтація на дію. На думку Ю. Куля, цей модус передбачає здатність особистості переходити до рішучих дій, а не зупинятися на стадії обдумування. Це передбачає високий рівень розвитку саморегуляції поведінки, яка, в свою чергу, зумовлює повноцінність наміру, тобто готовність втілювати намічене у життя. За умов повноцінності наміру перешкоди, що виникають в процесі діяльності, тягнуть за собою мимовільне підвищення зусиль суб'єкта для досягнення мети [18]. На думку В. Олефір, ситуація досягнення передбачає перехід від мотиваційного до вольового стану свідомості, який потребує від суб'єкта дії значних зусиль. Успішність реалізації мети залежить від особливостей контролю суб'єкта над дією не лише при іiі реалізації, а й, особливо, у випадку невдач [19, с. 85]. Це відповідає загальній тенденції інтернальної поведінки - мобілізації для подолання проблем без зовнішнього поштовху та контролю. Через усвідомлення вагомості власного впливу інтернал готовий переходити до рішучих дій, тоді як екстернал схильний «застрявати» на мотиваційній фазі. Особливо це стосується ситуацій неуспіху, коли інтернал вирішує почати змінювати свою поведінку задля очікуваного покращення результатів, а екстернал починає звинувачувати інших та жаліти себе.

Виокремлені нами умови позитивного впливу інтернальності на саморозвиток майбутніх психологів будуть перевірені у подальшому емпіричному дослідженні.

Конкретизуємо зміст психологічних умов позивного впливу інтернальності на готовність до саморозвитку студентів-психологів з урахуванням специфіки майбутніх професійних вимог.

Оптимістичний атрибутивний стиль майбутніх психологів у поєднанні з інтернальністю сприяє ï самоефективності, впевненості у власних здібностях. Як показав В. Шахов, особистісний оптимізм є ключовим детермінантом професійної самосвідомості студентів-психологів, пов'язаним 3 мотивацією навчальної та професійної діяльності. Віра у свою здатність стати кваліфікованим психологом допомагає долати труднощі навчально-професійного зростання, реалізувати свої задатки та нахили, зменшує страх перед важливими професійними рішеннями та викликами у майбутньому [20, с. 130-131]. За результатами емпіричного дослідження А. Шиліної та А. Низовець, оптимізм притаманний групі майбутніх психологів з високим рівнем готовності до змін. Оптимістичні студенти-психологи схильні сподіватися на успішне виконання намічених справ, оскільки не налаштовані на найгірший сценарій майбутніх подій. Серед цієї групи осіб переважають здобувачі вищої освіти, готові до подальшої інноваційної діяльності; їм властиві інтерналь- 
ність, висока мотивація саморозвитку, здатність до самоаналізу, генерації нових ідей та пошуку шляхів подолання існуючих проблем [21, с. 176].

Усвідомлення студентами-психологами власної відповідальності за результати майбутньої фахової діяльності $€$ однією 3 основних умов успішності їх самовдосконалення. Як свідчить дослідження Н. Фалько з колегами, високий рівень відповідальності є значущим показником професійно-особистісної зрілості майбутніх психологів, яка характеризується потребою у піклуванні про клієнтів, інтернальністю, прагненням до ефективного використання своїх знань та вмінь, компетентністю щодо конструктивного розв'язання життєвих проблем, вмотивованістю до якомога більш повної самореалізації [22, с. 319]. Водночас, як зазначає Б. Бригадир, готовність психолога до професійної діяльності передбачає не тільки високу самостійність та опору на себе при прийнятті рішень, але й здатність розділяти відповідальність 3 клієнтом, визнання його креативності та неповторності [23, с. 30-31]. Ми вважаємо, що реалістичність цілей професійної взаємодії, підтримка ресурсів самого клієнта щодо подолання життєвих труднощів та концентрація на використанні оптимальних методів впливу можуть попередити вигорання психолога, зумовлене прийняттям повної відповідальності за всі невдачі у професійній діяльності.

Під час інтернального контролю орієнтація на дію, готовність до активності забезпечують дієвість саморозвитку студентів-психологів. О. Тимошенко експериментально довів тісний зв'язок інтернальності майбутніх практичних психологів 3 суб'єктністю та готовністю до самоактуалізації. За результатами його дослідження, студентам із суб'єктним типом орієнтованості властиві високий рівень інтернальності у сфері досягнень, здатність виступати перетворювачем життєвої ситуації, виражене творче ставлення до життя, готовність до активних дій стосовно власного Я $[24$, с. 7$]$. Таку думку поділяє й В. Петришин, який розглядав інтернальність та суб'єктність майбутніх психологів у тісному зв'язку з такими їх якостями, як здатність робити вибір, проявляти наполегливість та послідовність у його втіленні, готовність до самостійного досягнення результату [25, c. $154-155]$.

Висновки та перспективи подальших досліджень. Не зважаючи на високу соціальну бажаність, інтернальність може мати негативний вплив на саморозвиток майбутніх психологів за умов: песимістичного атрибутивного стилю, тобто переконаності у наявності у себе стійких внутрішніх причин невдач, які неможливо змінити (недостатній рівень інтелекту або здібностей, негативні якості, що не підлягають корекції тощо); сконцентрованості на відповідальності за невдачу без спроб іiї подолання, «комплекс провини»; орієнтації на стан - «застрявання» на стадії рефлексії, неповноцінність намірів самозміни. У таких випадках інтернальний локус контролю може призвести до депресії, неврозу.

Подальшим розгортанням дослідження передбачено, що інтернальність буде мати більш виражений та однозначний позитивний вплив на готовність майбутніх психологів до саморозвитку при забезпеченні певних психологічних умов. До таких умов ми відносимо: 1) оптимістичний атрибутивний стиль, тобто пояснення навчально-професійних труднощів нестачею старанності або іншими контрольованими чинниками; забезпечує високу мотивацію навчально-професійної діяльності студентів-психологів, впевненість у власних можливостях та готовність до засвоєння нових видів діяльності; 2) приймання відповідальності за самостійне подолання труднощів без надмірної концентрації на власній провині; забезпечує прагнення майбутніх психологів до надання клієнтам висококваліфікованої допомоги та готовність поділяти 3 ними відповідальність за успішність розв'язання проблеми; 3) орієнтації на дію, готовність до рішучої діяльності щодо самовдосконалення; забезпечує суб'єктність студентів-психологів, їх наполегливість та активність під час здійснення особистісно-професійного саморозвитку.

Перспективою подальших наукових розвідок вважаємо експериментальну перевірку характеру впливу інтернальності на саморозвиток майбутніх психологів 3 урахуванням запропонованих психологічних умов.

\section{ЛITЕРАТУРА}

1. Шевченко Н.Ф. Дослідження професійної спрямованості майбутніх психологів. Вісник Дніпропетровського університету імені Альфреда Нобеля. Серія «Педагогіка і психологія». 2013. № 1(5). С. 95-101.

2. Черепєхіна О.А. Розвиток ціннісного ставлення до професійного саморозвитку у студентів-психологів засобами навчально-психологічного тренінгу. Науковий вісник Херсонського державного університету. Серія : Психологічні науки. 2015. Вип. 1(2). С. 51-55.

3. Rotter J.B. Generalized expectances for internal versus external control of reinforcement. Psychol. Monogr. 1966. V. 80. № 1. P. 11-28.

4. Варе И.С. Субъективный контроль будущих психологов с высокой и низкой степенью сформированности смысложизненных ориентаций. Науковий огляд. 2016. № 6 (27). С. 71-79. 
5. Рекешева Ф.М. Условия развития психологической готовности к профессиональной деятельности студентов-психологов : дис... канд. психол. наук: 19.00.13 / Астрахан. гос. ун-т. Астрахань, 2007. $156 \mathrm{c}$.

6. Шахов В.І. Психологічні особливості подолання складних життєвих ситуацій студентами-психологами. Розвиток особистості майбутнього психолога в умовах трансформації суспільства: монографія / В.І. Шахов, О.М. Паламарчук [та ін.]. Вінниця: ТОВ «Нілан-ЛТД», 2016. С. 7-19.

7. Кетлер-Митницька Т.С. Зміст і результати впровадження програми формування інтернальності як чинника готовності майбутніх психологів до особистісно-професійного саморозвитку. Проблеми сучасної психології : збірник наукових праць Кам'янець-Подільського національного університету імені Івана Огієнка, Інституту психології імені Г. С. Костюка НАПН України / за наук. ред. С. Д. Максименка, Л. А. Онуфрієвої. Вип. 46. Кам’янець-Подільський : Аксіома, 2019. C. $199-219$.

8. Реан А.А. Психология личности. Санкт-Петербург : Питер, 2016. 288 с.

9. Шамионов Р.М. Психология социального поведения личности : учеб. пособие. Саратов : Наука, 2009. $186 \mathrm{c}$.

10. Грузинська I.M. Психологічні умови розвитку творчої уяви дітей дошкільного віку: теоретичний аналіз проблеми. Науковий часопис національного педагогічного університету імені М. П. Драгоманова. Серія 12 : Психологічні науки. 2017. Вип. 5. С. 95-102.

11. Фернхен А., Хейвен П. Личность и социальное поведение. Санкт-Петербург : Питер, 2001. 368 с.

12. Фрейджер Р., Фейдимен Дж. Личность: теории, упражнения, эксперименты. Санкт-Петербург : Прайм-ЕВРОЗНАК, 2004. 608 с.

13. Хекхаузен Х. Мотивация и деятельность. 2-е изд. Санкт-Петербург : Питер; Москва : Смысл, 2003. $860 \mathrm{c}$.

14. Henderson V., Dweck C.S. Adolescence and achievement. At the threshold: Adolescent development / S. Feldman, G. Elliott (Eds.). Cambridge (MA) : Harvard University Press, 1990. P. 308-329.

15. Гордеева Т.О. Психология мотивации достижения. Москва : Смысл; Издательский центр «Академия», 2006. $336 \mathrm{c.}$

16. Малімон Л., Дучимінська Т. Психологічний аналіз взаємозв'язку атрибутивного стилю та рівня інтернальності студентів із мотивацією їх навчальної діяльності. Педагогіка і психологія професійної освіти. Львів, 2012. № 6. С. 127-137.

17. Карась Д.В. Теоретико-методологические подходы к пониманию интернальности как психологического феномена. Сибирский психологический журнал. 2017. № 64. С. 24-48.

18. Kuhl J. Motivational and functional helpessness: The moderating effect of state versus action-orientation. Journal of Personality and Social Psychology. 1981. V. 40. P. 155-170.

19. Олефір В.О. Інтелектуально-особистісний потенціал як ресурс саморегуляції суб'єкта. Особистість як суб 'єкт подолання кризових ситуацій: психологічна теорія і практика : монографія / За ред. С. Д. Максименка, С. Б. Кузікової, В. Л. Зливкова. Суми : Вид-во СумДПУ імені А. С. Макаренка, 2017. С. 81-105.

20. Шахов В.В. Особистісний оптимізм як детермінанта професійної самосвідомості майбутніх практичних психологів. Наукові записки Вінницького державного педагогічного університету імені Михайла Коиююбинського. Серія : Педагогіка і психологія. 2014. № 42(2). С. 128-133.

21. Шиліна А.А., Низовець А.О. Готовність до змін як чинник інноваційності студентів-психологів. Право і Безпека. 2016. № 4. С. 173-177.

22. Фалько Н.М., Гузь Н.В., Варіна Г.Б. Психологічні особливості актуалізації професійно-особистісної зрілості майбутнього психолога засобами гештальт-терапії. Інновачійні технології розвитку психологічних ресурсів особистості : монографія. Херсон : Вид-во ФОП Вищемирський В.С., 2019. C. $317-328$.

23. Бригадир Б.М. Проблема особистісної готовності психологів до професійної діяльності. Науковий вісник Херсонського державного університету. Серія : Психологічні науки. 2016. Вип. 5(1). C. 29-33.

24. Тимошенко О.А. Формування суб'єктної орієнтованості особистості майбутнього практичного психолога : автореф. дис. ... канд. психол. наук : 19.00.07 / Нац. пед. ун-т ім. М. П. Драгоманова. Київ, 2010. $20 \mathrm{c}$.

25. Петришин В.В. Формування професійно значущих якостей студентів-психологів. Науковий вісник Львівського державного університету внутрішніх справ. Серія психологічна. 2014. Вип. 1. C. $149-160$. 


\section{REFERENCES}

1. Shevchenko, N.F. (2013). Doslidzhennia profesiinoi spriamovanosti maibutnikh psykholohiv [Study of the future psychologists' professional orientation]. Visnyk Dnipropetrovskoho universytetu imeni Alfreda Nobelia. Seriia «Pedahohika i psykholohiia», 1(5) [in Ukrainian].

2. Cherepiekhina, O.A. (2015). Rozvytok tsinnisnoho stavlennia do profesiinoho samorozvytku u studentiv-psykholohiv zasobamy navchalno-psykholohichnoho treninhu [Development of students-psychologists' value attitude to professional self-development by means of educational and psychological training]. Naukovyi visnyk Khersonskoho derzhavnoho universytetu. Seriia : Psykholohichni nauky. Vyp. 1(2). 51-55 [in Ukrainian].

3. Rotter, J.B. (1966). Generalized expectances for internal versus external control of reinforcement. Psychol. Monogr. V. 80. № 1, 11-28 [in English].

4. Vare, I.S. (2016). Subjektivnyj kontrol' budushhih psihologov s vysokoj i nizkoj stepen'ju sformirovannosti smyslozhiznennyh orientacij [Subjective control of future psychologists with a high and low degree of of life-meaning orientations' formation]. Naukovij ogljad. № 6(27) [in Rassian].

5. Rekesheva, F.M. (2007). Uslovija razvitija psihologicheskoj gotovnosti k professional'noj dejatel'nosti studentov-psihologov [Conditions for the development of psychological readiness for student psychologists' professional activity]: candidate's thesis [in Rassian].

6. Shakhov, V.I. (2016) Psykholohichni osoblyvosti podolannia skladnykh zhyttievykh sytuatsii studentamy-psykholohamy [Psychological features of overcoming difficult life situations by psychology students]. Rozvytok osobystosti maibutnoho psykholoha v umovakh transformatsii suspilstva: monohrafiia: a monograph / V.I. Shakhov, O.M. Palamarchuk [ta in.]. Vinnytsia: TOV «Nilan-LTD» [in Ukrainian].

7. Ketler-Mytnytska, T.S. (2019). Zmist i rezultaty vprovadzhennia prohramy formuvannia internalnosti yak chynnyka hotovnosti maibutnikh psykholohiv do osobystisno-profesiinoho samorozvytku [The content and results of the program of internality formation as a factor of future psychologists' readiness for personal and professional self-development]. Problemy suchasnoi psykholohii : zbirnyk naukovykh prats Kamianets-Podilskoho natsionalnoho universytetu imeni Ivana Ohiienka, Instytutu psykholohii imeni H. S. Kostiuka NAPN Ukrainy / ed. by S. D. Maksymenko, L. A. Onufriieva. Vyp. 46. KamianetsPodilskyi : Aksioma, 199-219 [in Ukrainian].

8. Rean, A.A. (2016). Psihologija lichnosti [Psychology of personality]. Sankt-Peterburh : Piter [in Rassian].

9. Shamionov, R.M. (2009). Psihologija social'nogo povedenija lichnosti : ucheb. posobie [Psychology of social behavior of the person: textbook]. Saratov : Nauka [in Rassian].

10. Hruzynska, I. (2017). Psykholohichni umovy rozvytku tvorchoi uiavy ditei doshkilnoho viku: teoretychnyi analiz problemy [Psychological conditions for the development of creative imagination of preschool children: a theoretical analysis of problem]. Naukovyi chasopys natsionalnoho pedahohichnoho universytetu imeni M. P. Drahomanova. Seriia 12 : Psykholohichni nauky, 5, 95-102 [in Ukrainian].

11. Fernhen, A., \& Hejven, P. (2001). Lichnost' i social'noe povedenie [Personality and social behavior]. Sankt-Peterburg : Piter [in Rassian].

12. Frejdzher, R., \& Fejdimen, Dzh. (2004). Lichnost': teorii, uprazhnenija, jeksperimenty [Personality: theories, exercises, experiments]. Sankt-Peterburg : Prajm-EVROZNAK [in Rassian].

13. Hekhauzen, H. (2003). Motivacija i dejatel'nost' [Motivation and activity]. 2-e izd. Sankt-Peterburg : Piter; Moskva : Smysl [in Rassian].

14. Henderson, V., \& Dweck, C.S. (1990). Adolescence and achievement. At the threshold: Adolescent development / S. Feldman, G. Elliott (Eds.). Cambridge (MA) : Harvard University Press [in English].

15. Gordeeva, T.O. (2006). Psihologija motivacii dostizhenija [Psychology of achievement motivation]. Moskva : Smysl; Izdatel'skij centr «Akademija» [in Rassian].

16. Malimon, L., \& Duchiminska, T. (2012). Psihologichnij analiz vzaiemozvjazku atributivnogo stilju ta rivnja internalnosti studentiv iz motivaciieju yih navchalnoi dijalnosti [Psychological analysis of the relationship between students' attributive style and the internality level with the motivation of their educational activities]. Pedagogika i psihologija profesijnoi osviti. Lviv, 2012. № 6 [in Ukrainian].

17. Karas', D.V. (2017). Teoretiko-metodologicheskie podhody k ponimaniju internal'nosti kak psihologicheskogo fenomena [Theoretical and methodological approaches to understanding of internality as a psychological phenomenon]. Sibirskij psihologicheskij zhurnal. № 64 [in Rassian].

18. Kuhl, J. (1981). Motivational and functional helpessness: The moderating effect of state versus action-orientation. Journal of Personality and Social Psychology. V. 40 [in English].

19. Olefir, V.O. (2017). Intelektualno-osobystisnyi potentsial yak resurs samorehuliatsii subiekta [Intellectual and personal potential as a resource of self-regulation of the subject]. Osobystist yak subiekt podolannia kryzovykh sytuatsii: psykholohichna teoriia $i$ praktyka : monohrafiia / $\mathrm{Za}$ red. 
S.D. Maksymenka, S. B. Kuzikovoi, V.L. Zlyvkova. Sumy : Vyd-vo SumDPU imeni A. S. Makarenka [in Ukrainian].

20. Shakhov, V.V. (2014). Osobystisnyi optymizm yak determinanta profesiinoi samosvidomosti maibutnikh praktychnykh psykholohiv [Personal optimism as a determinant of professional self-awareness of future practical psychologist]. Naukovi zapysky Vinnytskoho derzhavnoho pedahohichnoho universytetu imeni Mykhaila Kotsiubynskoho. Seriia : Pedahohika i psykholohiia. № 42(2) [in Ukrainian].

21. Shylina, A.A., \& Nyzovets, A.O. (2016). Hotovnist do zmin yak chynnyk innovatsiinosti studentiv-psykholohiv [Readiness for change as a factor of innovation of students-psychologists]. Pravo i Bezpeka. № 4 [in Ukrainian].

22. Falko, N.M., Huz, N.V., \& Varina, H.B. (2019). Psykholohichni osoblyvosti aktualizatsii profesiino-osobystisnoi zrilosti maibutnoho psykholoha zasobamy heshtalt-terapii [Psychological features of actualization of professional and personal of the future psychologist' maturity by means of Gestalt therapy]. Innovatsiini tekhnolohii rozvytku psykholohichnykh resursiv osobystosti : monohrafiia. Kherson : Vyd-vo FOP Vyshchemyrskyi V.S. [in Ukrainian].

23. Bryhadyr, B.M. (2016). Problema osobystisnoi hotovnosti psykholohiv do profesiinoi diialnosti [The problem of personal readiness of psychologists for professional activity]. Naukovyi visnyk Khersonskoho derzhavnoho universytetu. Seriia : Psykholohichni nauky. 2016. Vyp. 5(1) [in Ukrainian].

24. Tymoshenko, O.A. (2010). Formuvannia subiektnoi oriientovanosti osobystosti maibutnoho praktychnoho psykholoha [Formation of subject orientation of the future practical psychologist' personality] : Extended abstract of candidate's thesis. Kyiv [in Ukrainian].

25. Petryshyn, V.V. (2014). Formuvannia profesiino znachushchykh yakostei studentiv-psykholohiv [Formation of professionally significant qualities of students-psychologists]. Naukovyi visnyk Lvivskoho derzhavnoho universytetu vnutrishnikh sprav. Seriia psykholohichna. Vyp. 1. [in Ukrainian]. 